\title{
Spontaneous Regression of Merkel Cell Carcinoma: Case Report
}

\author{
Branislav Bystricky (D) \\ Filip Kohutek (iD) ${ }^{2}$ \\ Zuzana Miklatkova ${ }^{2}$ \\ Tomas Sedlacek ${ }^{3}$ \\ Viliam Gal (iD) \\ Regina Lohajova Behulova ${ }^{5}$ \\ 'Oncology Department, Faculty Hospital \\ Trencin, Trencin, Slovakia and Faculty of \\ Healthcare, Alexander Dubcek University \\ of Trencin, Trencin, Slovakia; ${ }^{2}$ Oncology \\ Department, Faculty Hospital Trencin, \\ Trencin, Slovakia; ${ }^{3}$ Medicyt Trencin, \\ Trencin, Slovakia; ${ }^{4}$ Unilabs Slovakia, \\ Bratislava, Slovakia; ${ }^{5}$ Department of \\ Clinical Genetics, St. Elisabeth Cancer \\ Institute, Bratislava, Slovakia
}

\begin{abstract}
Merkel cell carcinoma (MCC) is a rare skin neuroendocrine tumor presumably arising from Merkel cells in the basal layer of epidermis. It is an aggressive tumor predominantly found on the head and neck area of elderly people, with a mortality rate around $41 \%$ for all stages. Complete spontaneous regression of MCC is seldom observed, mostly in elderly women. We describe complete spontaneous regression of large, histologically confirmed MCC in an elderly woman after biopsy, which occurred incidentally, while waiting for radical surgery with skin flap. Next-generation sequencing with SOPHiA Solid Tumor Plus Solution did not reveal any relevant gene mutations or rearrangements. An update of literature for these very rare cases is provided.
\end{abstract}

Keywords: skin neuroendocrine tumor, zygomatic region, next-generation sequencing

\section{Introduction}

Merkel cell carcinoma (MCC) is a rare skin neuroendocrine tumor presumably arising from Merkel cells in the basal layer of epidermis. These cells contain neurosecretory granules and some of them come into close vicinity of terminal nerves and external sheath of hair follicles. Function of these cells is most likely as slowly adapting mechanoreceptors. Another population of Merkel cells lack innervation, and their function is elusive. ${ }^{1}$ Genuine cellular origin of MCC is still a matter of controversy, as dermal fibroblasts, epidermal keratinocytes, and other cells found in skin have been suspected of being a cell of origin. ${ }^{2}$ Irrespective of these hypotheses, MCC is an aggressive tumor arising predominantly on the head and neck area of elderly people. Mortality rate for all stages from contemporary series from Queensland, Australia is around $41 \%{ }^{3}$ Significant survival differences are observed in relation to tumor stage, location, and age of patient. Elderly patients, above 80 years of age, are three times more likely to die from MCC within 5 years compared to those under 70 years. Moreover, tumors located on the trunk and lower limbs carry worse prognosis, as well as those with lymph node involvement or distant metastases. ${ }^{4}$

UV light exposure is one of the risk factors for MCC, as well as ongoing immunosuppression in transplant patients or in B-cell malignancies. In 2008, Feng et al identified human polyoma virus, so called Merkel cell polyomavirus (MCPyV) in MCC cells. ${ }^{5} \mathrm{MCPyV}$ is part of normal human flora, with primary infection occurring during childhood. Viral DNA is detected in more than $50 \%$ of healthy persons, without causing known disease. ${ }^{6}$ However, integration of this virus into the human genome is thought to contribute to MCC oncogenesis. MCPyV viral DNA integration was found
Correspondence: Branislav Bystricky Oncology Department, Faculty Hospital Trencin, Legionarska 28, Trencin, 9II7I, Slovakia

Tel +42I-32-656639I

Fax +42I-32-6520I04

Email branislav.bystricky@fntn.sk 
in $70-80 \%$ European and $24 \%$ Australian MCC patients. $^{7}$ The presence of MCPyV within MCC tumor cells may provide necessary immunostimulatory signal for systemic response, as demonstrated by higher number of intratumoral T-cells. $^{8}$

Tumor has a high propensity for local recurrence and systemic metastases. Standard treatment of local disease is surgery, sentinel lymph node staging, and adjuvant radiotherapy. ${ }^{9}$ Metastatic disease has dismal prognosis, but emerging treatments with anti-PD-L1 antibodies brought durable responses. ${ }^{10}$ Complete spontaneous regression of MCC was first described in 1986, and since then around 40 cases have been described in literature. ${ }^{11-15}$

Herein we report a complete regression after biopsy of an 88-year-old female with newly diagnosed MCC on her cheek.

\section{Case Study}

An 88-year old female patient presented with a progressively growing purple nodule on her right cheek (up to $5 \mathrm{~cm}$ ). She underwent incisional biopsy under surgical services and was referred to our oncology service (Figure 1). Her past medical history was notable for curatively treated gastric cancer 11 years ago. She was reviewed and diagnostic imaging (CT, MRI) was done. Contrast enhanced CT demonstrated large prominent lesion of the right zygomatic region with adjacent bone invasion but showed no distant metastatic spread (Figure 2). MRI of the head region confirmed this finding in the right zygomatic region (Figure 3). Histology showed small to medium-sized tumor cells with inconspicuous cytoplasm, displaying a saltand-pepper chromatin pattern. A perinuclear dot-like pattern

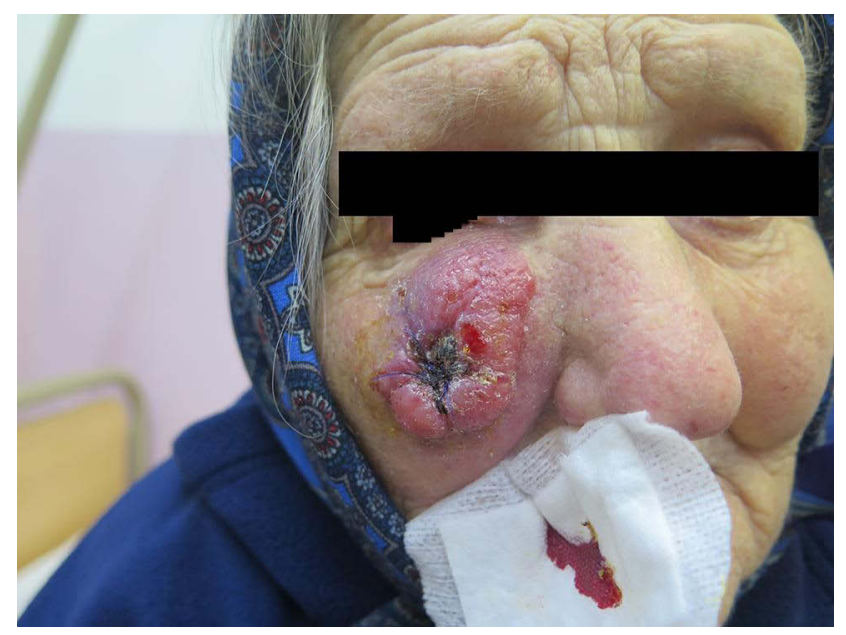

Figure I Pre-surgery photography of ulcerated violet tumor of the right zygomatic region.

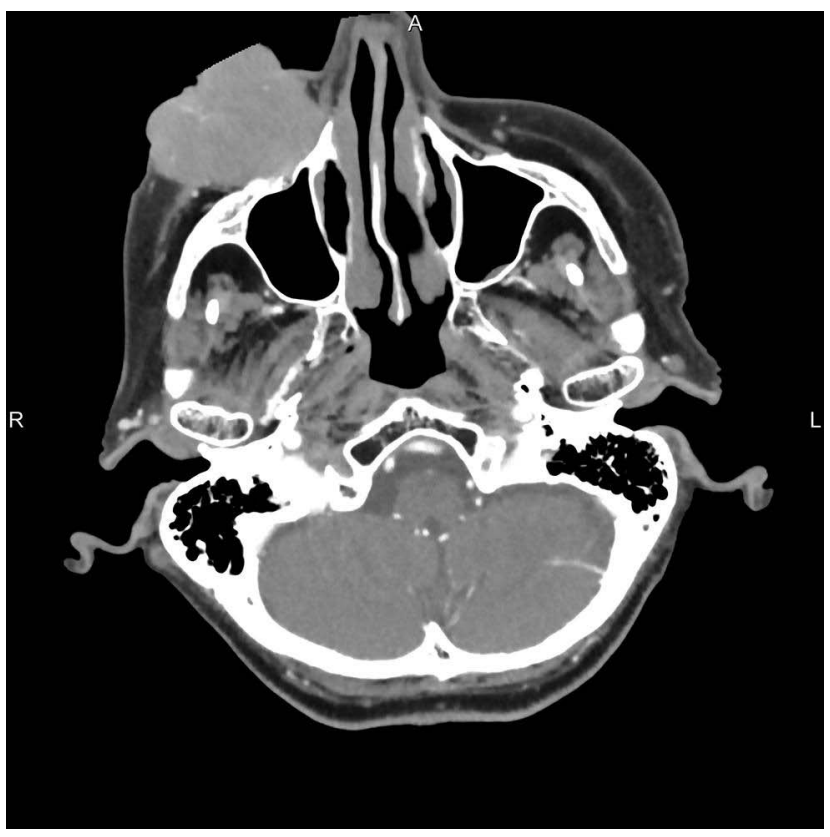

Figure 2 Contrast-enhanced CT of the head demonstrates a large vaulted solid heterogeneously enhancing mass lesion (size $45 \times 35 \mathrm{~mm}$ ) in the right infraorbital space with thinning the wall of the maxillary sinus. There is minimal mucosal thickening in the left maxillary sinus and nasal cavity.

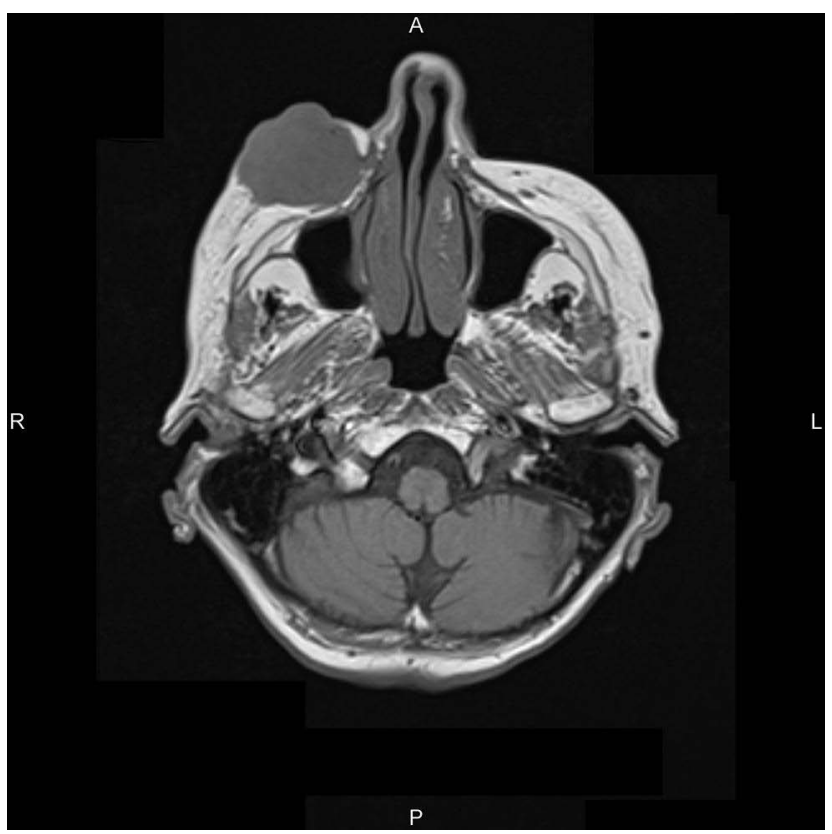

Figure 3 Axial enhanced TI-weighted MR imaging demonstrates a circumscribed enhancing tumor extending from subcutaneous tissue in the right infraorbital space (size $42 \times 31 \mathrm{~mm}$ ) with oppression of the anterior wall of the maxillary sinus.

of CK20 was observed. Tumor cells stained for CD56, as well as synaptophysin and chromogranin (Figures 4-7). A diagnosis of Merkel cell carcinoma located at the right infraorbital area was made. Her AJCC stage based on 


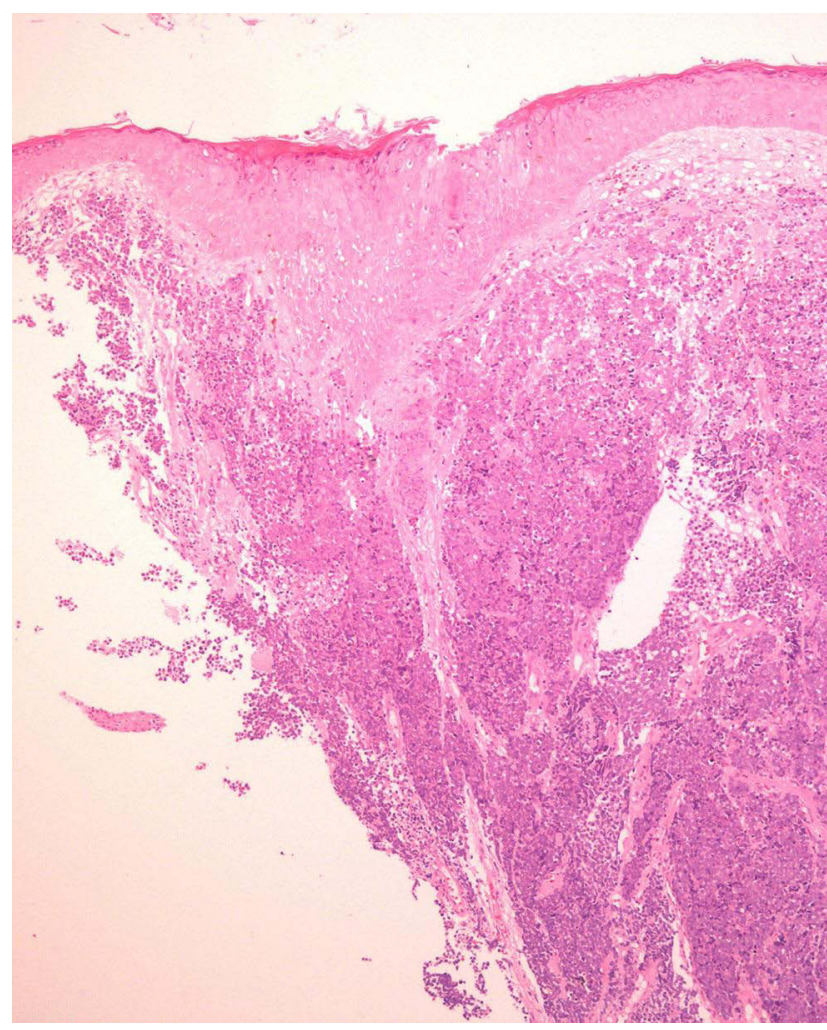

Figure 4 Incisional biopsy (HE, 40x): specimen taken from the center of the tumor mass. Malignant solid tumors involved dermis and margin.

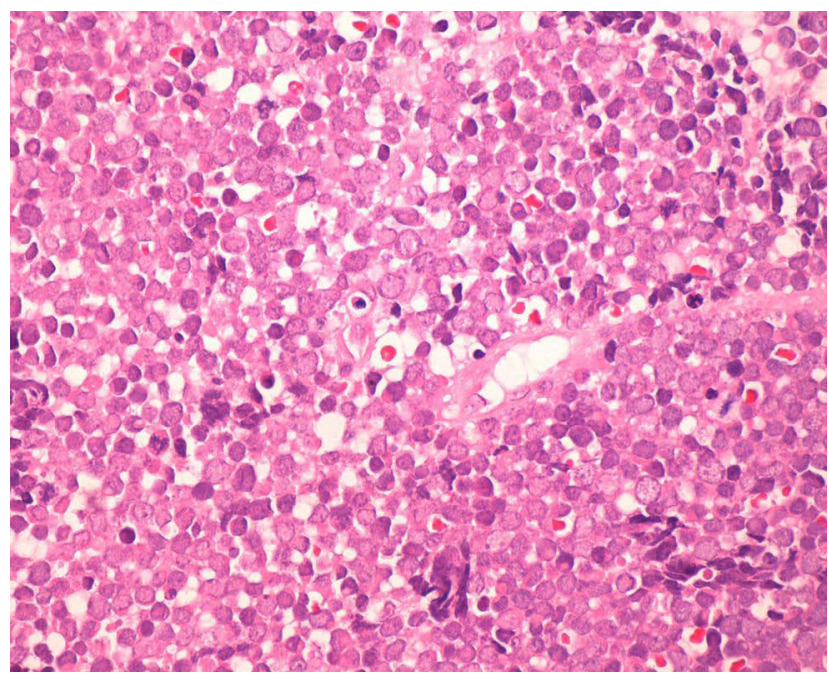

Figure 5 Merkel cell carcinoma. Detail 400x. Small to medium-sized tumor cells with inconspicuous cytoplasm display a salt-and-pepper chromatin pattern.

clinical examination was cT2N0, stage IIA. In this patient with rare cancer, we performed an analysis of the somatic panel of genes associated with oncological diseases from tumor DNA and RNA using molecular genetic methods. The principle of molecular genetic analysis using Sophia

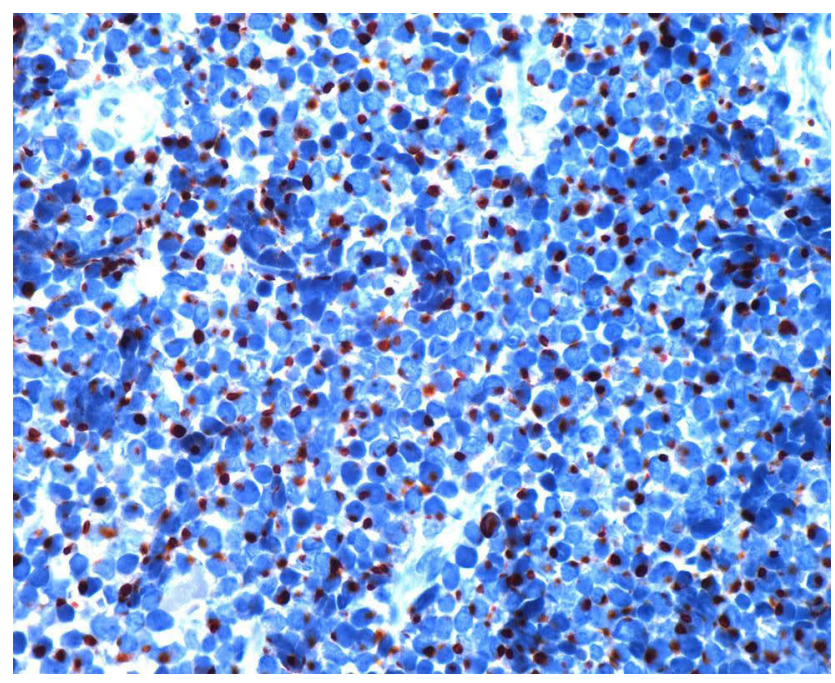

Figure 6 Merkel cell carcinoma. Detail 400x. Immunoexpression of CK20 in the tumor cells in a characteristic perinuclear dot-like pattern.

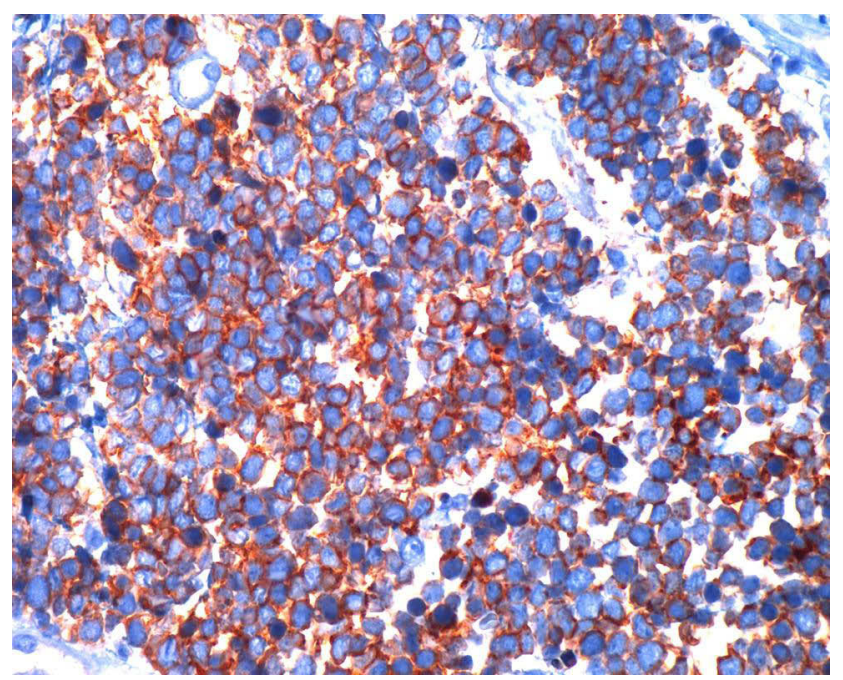

Figure 7 Merkel cell carcinoma. Detail 400x. Tumor cells are immunoreactive for neuroendocrine marker CD56 (as well as synaptophysin and chromogranin, not shown).

Tumor Solid Plus Solution (STS+) is the detection of somatic DNA variants in 42 genes, analysis of large gene rearrangement (somatic $\mathrm{CNV}$ ) in 24 genes, detection of 137 clinically relevant RNA fusions, and MSI analysis (microsatellite instability). We did not detect any somatic variant, large gene rearrangement, or RNA fusion with clinical significance in the patient according to TIER criteria (level IA, IB, IIC, IID) or pathogenic effect (class 4 and 5) according to American College of Medical Genetics and Genomics (ACMG) criteria. ${ }^{16-18}$

We have not done Merkel cell polyoma virus (MCPyV) detection (PCR or immunohistochemistry) as these tests 


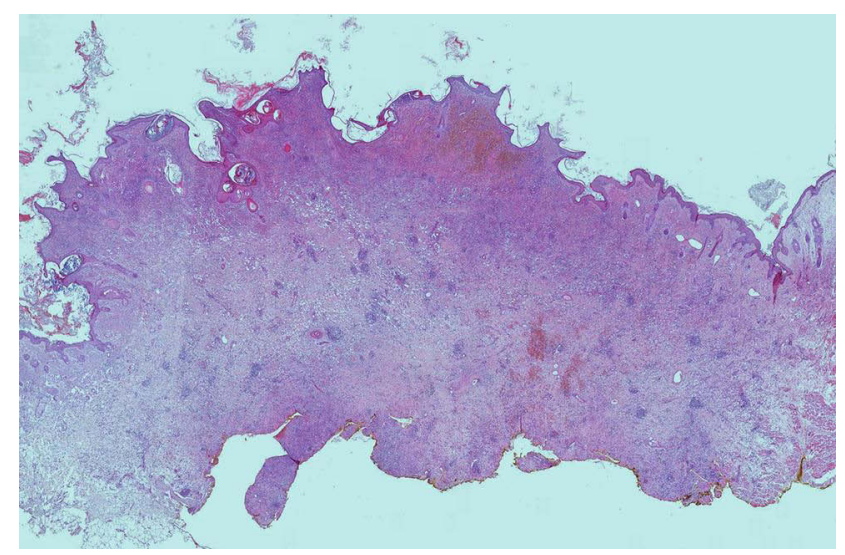

Figure 8 Excisional biopsy (HE, 20x). Regressive changes in the dermis, represented by fibrotization, permeated by chronic inflammatory infiltrate, sporadic neutrophils, and giant cell response. The epidermis histologically corresponds to inflamed seborrheic keratosis, with undulated and slightly acanthotic epithelium, with marked hyperkeratosis and formation of keratin pseudocysts, partially covered with mixed inflammatory exudate.

were not available in any pathology department in our country.

After the diagnosis and no dissemination on staging CT scan, she was referred to a plastic surgeon for radical treatment. Radical surgery was performed 3 months after initial biopsy. A notable regression of lesion was noted, nevertheless, radical surgical excision with skin graft was done. On macroscopic examination, excision of the skin measured 47x39x14 mm (with subcutaneous tissue). Centrally was present an exophytic tumor lesion $35 \times 23 \times 4 \mathrm{~mm}$ with a gray friable surface, with two sutures present in its middle. Excisional biopsy was processed completely in 13 blocks.
Histological examination showed only regressive changes in the dermis, characterized by fibrotization, chronic inflammatory infiltrate, and a giant cell response. No MCC cells were found in the specimen anymore (Figures 8 and 9). Even though regression of tumor was observed clinically, radical excision of remaining tissue is the only way to confirm spontaneous regression. After surgery, she was well and was attending our follow-up clinic (Figure 10).

Unfortunately, she died of COVID pneumonia in our hospital 14 months after initial diagnosis, with no evidence of recurrence of MCC.

\section{Discussion}

According to the SEER database in the US, the annual incidence of MCC is $0.4 / 100,000$, with incidence increasing in the last decade. Complete spontaneous regression is defined as disappearance of tumor without treatment. Often, mononuclear inflammatory cell infiltrate is seen. Estimated incidence of this event in MCC is $1.7-3 \%$, compared to $0.01 \%$ in other solid tumors. ${ }^{19}$ Complete spontaneous regression in other cutaneous malignancies, such as melanoma, was described at a rate of $0.2 \%$ for metastatic disease and up to $5-10 \%$ for primary lesions. However, these regressions are usually not further histologically proven as complete and may well be only partially regressed tumors. ${ }^{20,21}$ Unlike spontaneous regression in other tumors (eg melanoma), complete spontaneous regression in MCC signifies a better prognosis and only one distant and one regional recurrence after this event has been reported. ${ }^{22,23}$ There were reports of MCC spontaneously regressing in

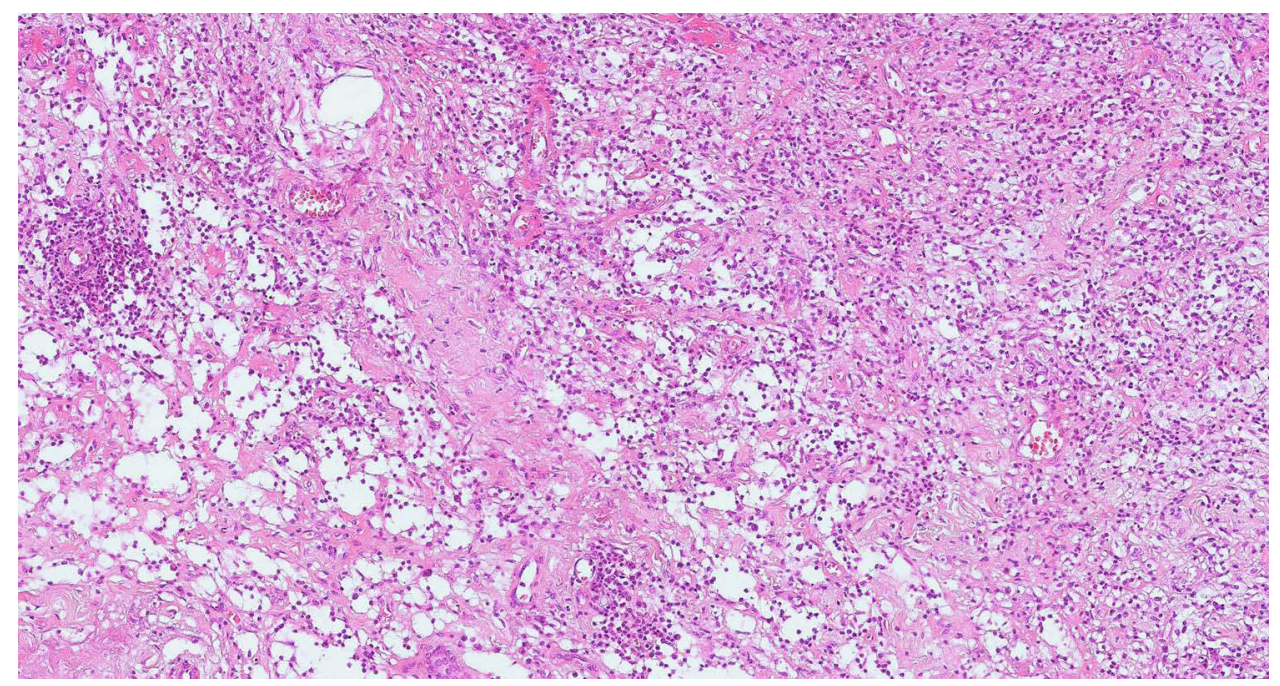

Figure 9 Detail, HE, 200x. Chronic inflammatory infiltrate consists of a mixture of T- and B-lymphocytes, with numerous plasma cells and histiocytes. Focal giant cell reaction and neutrophils. Residual Merkel cell carcinoma was excluded by negativity with cytokeratins (OSCAR, CK20) and neuroendocrine markers (synaptophysin, chromogranin). 


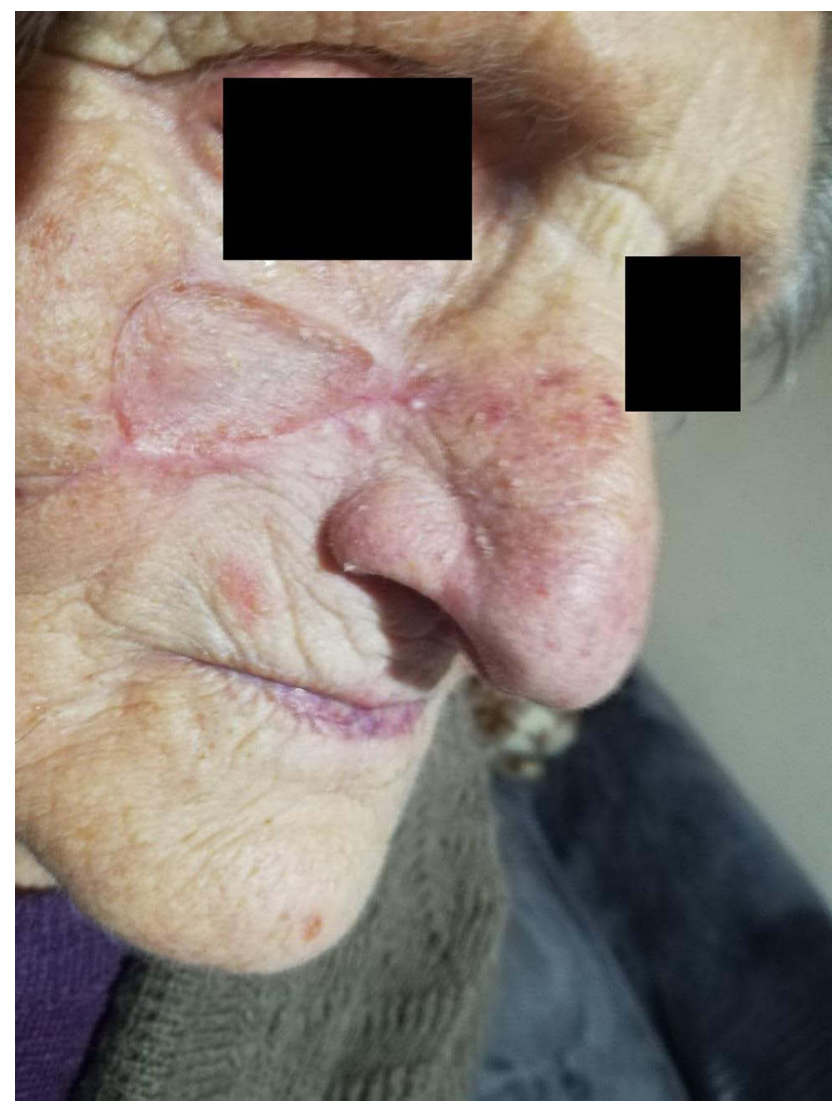

Figure 10 First follow- up control, 3 months after plastic surgery. Skin flap covering the original tumor bed, no evidence of local disease progression.

metastatic lymph nodes and after withdrawal of immunosuppression. ${ }^{24,25}$ We have reviewed and summarized published literature on complete spontaneous regression from 2017 onwards (added to 34 cases reviewed by Guiote et al in $2017)^{26}$ (Table 1). Now over 50 cases of spontaneous regression of MCC have been published, mostly in elderly women. Most frequent site of MCC is sun-exposed face. Majority of cases had biopsy to confirm diagnosis. After a median of 2 months (range: $2-40$ weeks), complete regression was observed. In few cases, regression of regional lymphadenopathy or metastatic disease was described as well. Six cases of regression of recurrences were described, so-called secondary spontaneous regression. ${ }^{27,28}$ Mechanism of spontaneous regression is unclear. T-cell mediated immune response and apoptosis were usually identified in regressed lesions. However, biopsy itself does not commonly induce intratumoral CD8 T-cell infiltrate. ${ }^{29}$ In so-called secondary spontaneous regressions, regressions occurred without clear trigger.

Given the small number of cases published in the literature, it is difficult to identify a set of factors that predispose a patient to $\mathrm{MCC}$ regression. $\mathrm{MCPyV}$ infection, immune response, and MCC prognosis are poorly understood. ${ }^{8}$ Whether the presence of MCPyV correlates with complete spontaneous regression will need further investigation, as we have only found a handful of MCPyV reported cases. However, MCC has shown to be an immunologically responsive tumor and avelumab, a first immune checkpoint inhibitor, was approved by the FDA for treatment for metastatic MCC, including chemotherapy-naïve patients.

\section{Conclusion}

Although the number of reported cases of complete spontaneous regression is not overwhelming, oncologists and surgeons should be aware of this phenomenon. Many of these events began shortly after initial, diagnostic biopsy. In a patient with suspected ongoing spontaneous regressing tumor, an

Table I Complete Spontaneous Regression of Merkel Cell Carcinoma: Review of Literature from 2017-202I

\begin{tabular}{|c|c|c|c|c|c|c|c|c|c|}
\hline Author & Age & Sex & Location & $\mathbf{B x}$ & $\mathbf{L N}$ & Met & MCPyV & Time to Regression & Follow-Up \\
\hline Terui et $\mathbf{a l}^{30}$ & 94 & $\mathrm{~F}$ & Cheek & Y & $\mathrm{N}$ & $\mathrm{N}$ & $\mathrm{n} / \mathrm{a}$ & 3 wks & - \\
\hline Vásquez-Ramírez et al $^{3 !}$ & 59 & $\mathrm{~F}$ & Forehead & $Y$ & $\mathrm{~N}$ & $\mathrm{~N}$ & $\mathrm{n} / \mathrm{a}$ & 12 wks & 4 years \\
\hline Branch et $\mathrm{al}^{32}$ & 96 & $\mathrm{~F}$ & Chest & Y & $\mathrm{N}$ & $\mathrm{N}$ & $\mathrm{n} / \mathrm{a}$ & 24 wks & - \\
\hline \multirow[t]{2}{*}{ Marcoval et al' } & 69 & M & Parietal & Y & $\mathrm{N}$ & $\mathrm{N}$ & + & 5 wks & 4 years \\
\hline & 72 & $\mathrm{~F}$ & Tibial & $Y$ & $\mathrm{~N}$ & $N$ & + & 4 wks & 2 years \\
\hline Baker et al $^{13}$ & 65 & M & $\mathrm{n} / \mathrm{a}$ & $Y$ & $\mathrm{~N}$ & $\mathrm{~N}$ & + & 6.5 wks & $?$ \\
\hline Nijjar et al $^{33}$ & 77 & $M$ & Breast & $Y$ & $\mathrm{~N}$ & $N$ & - & 2 wks & 3 years \\
\hline Sanabria et al $^{15}$ & 84 & M & Forehead & $Y$ & $Y$ & $Y$ & $\mathrm{n} / \mathrm{a}$ & 4 wks & 2 years \\
\hline Leung et $\mathrm{al}^{14}$ & 71 & $\mathrm{~F}$ & Orbit & $Y$ & $N$ & $N$ & $\mathrm{n} / \mathrm{a}$ & 5 wks & 3.5 years \\
\hline Current report & 88 & $\mathrm{~F}$ & Cheek & Y & $\mathrm{N}$ & $\mathrm{N}$ & $\mathrm{n} / \mathrm{a}$ & 12 wks & I year \\
\hline
\end{tabular}


active close surveillance can be considered. CT/PET scans could be helpful in monitoring patients with ongoing responses, due to their capability to assess metabolic activity of the tumor. Nevertheless, complete excision of regressing lesion is still the most exact way to confirm spontaneous regression of tumor.

\section{Abbreviations}

MCC, Merkel cell carcinoma; HE, hematoxylin-eosin; AJCC, American Joint Committee on Cancer; CNV, copy number variation; ACMG, American College of Medical Genetics and Genomics; COVID, coronavirus disease; M/F, male/female; MCPyV, Merkel cell polyoma virus; n/a, not available.

\section{Consent Statement}

Informed consent with publication was obtained from next-of-kin of the deceased patient. Institutional approval was not needed, as per our hospital standard operating procedures, approval is only needed when discussing hospital economic and staffing policies.

\section{Disclosure}

The authors report no conflicts of interest.

\section{References}

1. Barbieri JS, Wanat K, Seykora J. Skin: basic structure and function. In: Pathobiology of Human Disease: A Dynamic Encyclopedia of Disease Mechanisms. Academic Press; 2014:1134-1144. doi:10.1016/B9780-12-386456-7.03501-2

2. Pietropaolo V, Prezioso C, Moens U. Merkel cell polyomavirus and Merkel cell carcinoma. Cancers. 2020;12(7):1-38. doi:10.3390/ CANCERS12071774

3. Becker J, Stang A, DeCaprio J, et al. Merkel cell carcinoma. Nat Rev Dis Primers. 2017;3. doi:10.1038/NRDP.2017.77

4. Youlden DR, Soyer HP, Youl PH, Fritschi L, Baade PD. Incidence and survival for Merkel cell carcinoma in Queensland, Australia, 19932010. JAMA Dermatol. 2014;150(8):864. doi:10.1001/jamader matol.2014.124

5. Feng H, Shuda M, Chang Y, Moore PS. Clonal integration of a polyomavirus in human Merkel cell carcinoma. Science. 2008;319 (5866):1096-1100. doi:10.1126/science.1152586

6. Tabachnick-Cherny S, Pulliam T, Church C, Koelle DM, Nghiem P. Polyomavirus-driven Merkel cell carcinoma: prospects for therapeutic vaccine development. Mol Carcinog. 2020;59(7):807-821. doi: $10.1002 / \mathrm{mc} .23190$

7. Garneski KM, Warcola AH, Feng Q, Kiviat NB, Helen Leonard J, Nghiem P. Merkel cell polyomavirus is more frequently present in North American than Australian Merkel cell carcinoma tumors. J Invest Dermatol. 2009;129(1):246-248. doi:10.1038/jid.2008.229

8. Triozzi P, Fernandez A. The role of the immune response in Merkel cell carcinoma. Cancers. 2013;5(4):234-254. doi:10.3390/cancers5010234

9. Merkel cell carcinoma v1.2021. NCCN guidelines; 2001. Available from: https://www.nccn.org/professionals/physician_gls/pdf/mcc.pdf. Accessed September 4, 2021.
10. D'Angelo S, Bhatia S, Brohl A, et al. Avelumab in patients with previously treated metastatic Merkel cell carcinoma: long-term data and biomarker analyses from the single-arm Phase 2 JAVELIN Merkel 200 trial. J Immunother Cancer. 2020;8(1). doi:10.1136/JITC-2020-000674

11. Marcoval J, Valentí-Medina F, Penín RM, Bermejo J. Complete spontaneous regression of the primary tumor in Merkel cell carcinoma. Actas Dermosifiliogr. 2018;109(8):752-754. doi:10.1016/j.adengl.2018.07.013

12. O'rourke MGE, Bell J. Merkel cell tumor with spontaneous regression. J Dermatol Surg Oncol. 1986;12(9):994-996. doi:10.1111/j.1524-4725.1986.tb02143.x

13. Baker M, Roman JW, Reuben A, et al. Abstract 4676: spontaneous regression of Merkel cell carcinoma is driven by adaptive immune activation and clonal T cell expansion. Cancer Res. 2018. doi:10.1158/1538-7445.am2018-4676

14. Leung VC, Antonios R, Désy D, Rahal A, Boulos PR. A case of complete spontaneous regression of extensive Merkel cell carcinoma involving the orbit. Can J Ophthalmol. 2021;56(1):e13-e15. doi:10.1016/j.jcjo.2020.06.022

15. Sanabria A, Vega I, Sánchez L. Active surveillance after complete spontaneous regression of a metastatic Merkel cell carcinoma of the head. Arch Head Neck Surg. 2020;49:e0072020. doi:10.4322/ahns.2020.0011

16. Richards S, Aziz N, Bale S, et al. Standards and guidelines for the interpretation of sequence variants: a joint consensus recommendation of the American college of medical genetics and genomics and the association for molecular pathology. Genet Med. 2015;17 (5):405-423. doi:10.1038/gim.2015.30

17. Li MM, Datto M, Duncavage EJ, et al. Standards and guidelines for the interpretation and reporting of sequence variants in cancer. $J \mathrm{Mol}$ Diagn. 2017;19(1):4-23. doi:10.1016/j.jmoldx.2016.10.002

18. den Dunnen JT, Dalgleish R, Maglott DR, et al. HGVS recommendations for the description of sequence variants: 2016 update. Hum Mutat. 2016;37(6):564-569. doi:10.1002/humu.22981

19. Sais G, Admella C, Soler T. Spontaneous regression in primary cutaneous neuroendocrine (Merkel cell) carcinoma: a rare immune phenomenon? J Eur Acad Dermatol Venereol. 2002;16(1):82-83. doi:10.1046/j.1468-3083.2002.374_2.x

20. Menzies SW. Complete regression of primary cutaneous malignant melanoma. Arch Surg. 1997;132(5):553. doi:10.1001/ archsurg.1997.01430290099020

21. King M, Spooner D, Rowlands DC. Spontaneous regression of metastatic malignant melanoma of the parotid gland and neck lymph nodes: a case report and a review of the literature. Clin Oncol. 2001;13(6). doi:10.1053/clon.2001.9315

22. Kobayashi Y, Nakamura M, Kato H, Morita A. Distant recurrence of Merkel cell carcinoma after spontaneous regression. $J$ Dermatol. 2019;46(4):e133-e134. doi:10.1111/1346-8138.14652

23. Jansen S, Groeneveld-Haenen CP, Klinkhamer PJ, Roumen RM. Spontaneous regression and recurrence of stage III Merkel cell carcinoma. BMJ Case Rep. 2015;2015:bcr2014208344. doi:10.1136/ bcr-2014-208344

24. Longo R, Balasanu O, Chastenet de Castaing M, et al. A spontaneous regression of an isolated lymph node metastasis from a primary unknown Merkel cell carcinoma in a patient with an idiopathic hyper-eosinophilic syndrome. Am J Case Rep. 2018;19:1437-1440. doi:10.12659/AJCR.911840

25. Muirhead R, Ritchie D. Partial regression of Merkel cell carcinoma in response to withdrawal of azathioprine in an immunosuppression-induced case of metastatic Merkel cell carcinoma. Clin Oncol. 2007;19(1):96. doi:10.1016/J.CLON.2006.10.001

26. Guiote V, Cunha F, Pinho A, Brinca A, Vieira R. Advanced Merkel cell carcinoma: a new case of spontaneous regression. Revista SPDV. 2017;75(3):301-304. doi:10.29021/spdv.75.3.822

27. Junquera L, Vicente JC, Fresno MF, Torre A, Garcfa-Consuegra L. Complete spontaneous regression of Merkel cell carcinoma. Ann Orol Rhinol Laryngol. 2005;114(5):376-380. doi:10.1177/000348 940511400507 
28. Berkowitz AS, Neuman T, Frenkel S, Eliashar R, Weinberger JM, Hirshoren N. FDG-PET/CT for spontaneous regression of metastatic Merkel cell carcinoma: friend or foe? Isr Med Assoc J. 2019;21 (1):63-64.

29. Koba S, Paulson KG, Nagase K, et al. Diagnostic biopsy does not commonly induce intratumoral CD8 T cell infiltration in Merkel cell carcinoma. PLoS One. 2012;7. doi:10.1371/journal.pone.0041465

30. Terui H, Fujimura T, Kakizaki A, Furudate S, Aiba S. Merkel cell carcinoma with spontaneous regression: a case report and immunohistochemical study. Case Rep Dermatol. 2016;8(1):52-58. doi:10.1159/000444317
31. Vásquez-Ramírez M, Puebla-Miranda M, Cuestas-Mejías TC, Cortés- Gutiérrez ME, González-Alcudia AA. Remisión espontánea de tumor de células de Merkel. Correspondencia Spontaneous remission of Merkel cell carcinoma. Dermatol Rev Mex. 2017;61 (3):245-252.

32. Branch S, Maloney K, Purcell SM. Spontaneous regression of Merkel cell carcinoma. Cutis. 2018;101(4):301-305.

33. Nijjar Y, Bigras G, Tai P, Joseph K. Spontaneous regression of Merkel cell carcinoma of the male breast with ongoing immune response. Cureus. 2018;10(11):e3589. doi:10.7759/cureus.3589

\section{Publish your work in this journal}

The International Medical Case Reports Journal is an international, peer-reviewed open-access journal publishing original case reports from all medical specialties. Previously unpublished medical posters are also accepted relating to any area of clinical or preclinica science. Submissions should not normally exceed 2,000 words or 4 published pages including figures, diagrams and references. The manuscript management system is completely online and includes a very quick and fair peer-review system, which is all easy to use. Visit http://www.dovepress.com/testimonials.php to read real quotes from published authors. 